\section{IHTEPНЕТ-МАРКЕТИНГ У ДІЯЛЬНОСТІ БІБЛІОТЕК УКРАЇНИ}

\section{Тетяна Гранчак,}

завідувач відділу з охорони інтелектуальної власності Національної бібліотеки України імені В. І. Вернадського, д-р наук із соціальних комунікацій, ст. наук. співроб.

(Київ, Україна) e-mail:granchakt@ukr.net ORCID: https://orcid.org/0000-0001-7854-580X

\section{таісія Скітер,} магістрантка кафедри інформаційних технологій Київського національного університету культури і мистецтв (Київ, Україна) e-mail: tayaskyter@gmail.com

Сьогодні бібліотечні інституції в Україні переживають кризовий стан, обумовлений комплексом причин техніко-технологічного, сервісно-методичного, фінансового, організаційно-управлінського характеру. Одним зі шляхів подолання негативних тенденцій у розвитку вітчизняних бібліотек, посилення їх конкурентоспроможності $є$ впровадження в бібліотечну діяльність інтернет-маркетингу як системного підходу просування продуктів і послуг бібліотеки.

Стаття присвячена визначенню характерних особливостей здійснення інтернетмаркетингу бібліотеками України. Інтернет-маркетинг розглядається як сукупність інструментів і напрямів діяльності установи, починаючи від дослідження середовища (ринку і суб'єктів ринкових відносин у мережі інтернет) і закінчуючи просуванням інтернетбрендів і налагодженням системи їх обслуговування.

На основі застосування системного методу, який обумовив розгляд окремих видів бібліотечної діяльності, продуктів і послуг із позицій інтернет-маркетингу як системи, методів аналізу контенту, включеного спостереження, експерименту охарактеризовано підходи до реалізації інтернет-маркетингу в діяльності бібліотек України.

Виявлено використання бібліотеками України лише деяких інструментів інтернет-маркетингу в рамках реалізації окремих напрямів маркетингової діяльності. Основними онлайновими маркетинговими комунікаціями, які сьогодні використовуються бібліотеками України, є бібліотечні сайти, представництва бібліотек у соціальних мережах, меншою мірою онлайнові і традиційні 3МІ. За допомогою масмедіа бібліотеками проводяться кампанії з ребрендингу, оновлення іміджу установ, донесення до користувачів інформації стосовно модернізації бібліотечно-інформаційного сервісу - надання поряд із традиційними для бібліотек продуктами і послугами доступу до онлайнового сервісу та інноваційних інтерактивних заходів.

Акцентовано потребу посилення аналітичного та управлінського напрямів інтернет-маркетингу в бібліотечній діяльності, а саме зосередження уваги на вивченні конкурентів і ринку, ефективності функціонування різних інструментів інтернет-маркетингу та реалізації його різних напрямів, а також необхідність розробки виваженої маркетингової стратегії в інтернет-середовищі і організації відповідно до неї внутрішніх маркетингових процесів.

Ключові слова: інтернет-маркетинг, бібліотека, бібліотечна діяльність, бібліотечний маркетинг, імідж, PR, комунікація. 
Український журнал з бібліотекознавства та інформаційних наук. Випуск 4 (2019) Ukrainian Journal on Library and Information Science. Issue 4 (2019)

\section{ВСТУП.}

В умовах стрімкого процесу формування інформаційного суспільства, головними ресурсами і продуктами виробництва якого $є$ інформація і знання, для бібліотек як інформаційно-комунікаційних комплексів актуалізується завдання 3 популяризації своїх інформаційних продуктів і послуг. Сьогодні одним з найефективніших каналів маркетингу став інтернет. Намагаючись посилити свою конкурентоспроможність і зберегти суспільне призначення, українські бібліотеки інтуїтивно почали використовувати окремі інструменти інтернет-маркетингу: створювати інтернет-сайти, сторінки в соціальних мережах, спрямовуючи зусилля на покращення іміджу бібліотеки, залучення нових користувачів, рекламу бібліотечних фондів і послуг. Утім для забезпечення максимальної ефективності такої діяльності вона має здійснюватись на основі системного підходу з використанням наявних на сьогодні в галузі інтернет-маркетингу методик.

\section{ТЕОРЕТИЧНЕ ПІДГРУНТЯ.}

Зазвичай під поняттям інтернет-маркетингу розуміється теорія і практика організації маркетингу в інтернет-середовищі. На початку 2000 -х років I. Успенський запропонував структуру інтернет-маркетингу, яка формується з таких компонентів, як маркетингові дослідження, товарна політика, ціноутворення, розподільча політика, комунікативна політика (Успенский, 2003). Оптимізовану структуру інтернет-маркетингу згодом презентував Р. Стокс (Stokes, 2014, с. 14), який всі його компоненти розподілив по чотирьох великих групах - Думати (маркетингові дослідження, стратегія і план), Створювати (створення продуктів, починаючи від веб-сайтів та відео і закінчуючи рекламними банерами і застосунками), Залучати (інструменти залучення і просування для вибудовування відносин із клієнтами) і Оптимізовувати (відстеження та аналіз ефективності маркетингових кампаній).

Маркетингові дослідження в структурі інтернет-маркетингу складаються переважно $з$ досліджень конкурентного і споживацького середовищ, а також досліджень ринку інтернету. Крім того, за Р. Стоксом, до маркетингових досліджень варто відносити вивчення ефективності самих маркетингових кампаній із метою оптимізації діяльності (Stokes, 2014, с. 14). Товарна політика включає розробку нових товарів (на основі даних досліджень наповненості ринку, наявних попиту і пропозиції), організацію сервісного обслуговування і підтримку маркетингового оточення товарів і відповідає компоненту Створювати моделі інтернет-маркетингу Р. Стокса. Для ціноутворення важливим $є$ забезпечення його гнучкості (знову-таки, виходячи з даних досліджень структури ринку). Розподільча політика складається з двох напрямів: створення умов для можливості реалізації товарів через інтернет, а також забезпечення можливості оплати через інтернет. 3 усіх компонентів інтернет-маркетингу найбільш складним є комунікативна політика, яка включає формування системи інтернет-комунікацій, проведення рекламних кампаній, стимулювання збуту, організацію зв’язків із громадськістю з використанням інтернет-технологій, створення і просування інтернет-брендів (Успенский, 2003). Ціноутворення, розподільча політика і комунікативна політика є складовими компонента Залучення моделі інтернет-маркетингу Р. Стокса.

Узагальнюючи, можна підсумувати, що інтернет-маркетинг як процес включає систему дій і заходів, починаючи від дослідження середовища (ринку і суб’єктів 
ринкових відносин у мережі інтернет) і закінчуючи просуванням інтернет-брендів і налагодженням системи їх обслуговування.

На сьогодні аналізом і узагальненням різних аспектів проблематики маркетингу в мережі інтернет займаються такі теоретики і практики, як М. Акулич (Акулич, 2017, 2019), Р. Блай (Bly, 2018), Б. Брен (Bren, 2019), П. Бхатья (Bhatia, 2019), В. Голик та І. Ханан (Ханан, \& Голик, 2018), Б. Завері та П. Амін (Zaveri, \& Amin, 2019), П. і К. Каур та А. Патак (Kaur, Pathak, \& Kaur, 2015), Д. Кеннеді та У. Філліпс (Кеннеди, \& Филлипс, 2017), К. Хелсен (Helsen, 2019), Д. Чеффі та Ф. Еліс-Чедвік (Chaffey, \& Ellis-Chadwick, 2019), А. Чарлсворт (Charlesworth, 2018) та ін., які обгрунтовують поняття інтернет-маркетингу, його напрями та інструменти, обумовлені регіональною специфікою і галуззю особливості реалізації.

У межах бібліотекознавства увага дослідників на разі зосереджена на вивченні окремих маркетингових інструментів, таких як веб-сайти бібліотек, бібліотечні сторінки в соціальних медіа, бібліотечний PR тощо, які розглядались такими науковцями, як Д. Алойсіус, П. Ава та А. Аквасія (Aloysius, Awa, \& Aquaisua, 2019), Г. Булахова (Булахова, 2016, 2017), Т. Гранчак (Гранчак, 2016), М. Кейсі та Л. Савастинюк (Casey, \& Savastinuk, 2007), O. Мар'їна (Мар'їна, 2017), Дж. Мейнес (Maness, 2006), С. Ростовцев (Ростовцев, 2017), М. Самсонов (Самсонов, 2012), В. Струнгар (Струнгар, 2014), А. Тарасевич (Тарасевич, 2016), Л. Філіпова (Філіпова, 2012) та ін. Комплексної характеристики специфіки реалізації бібліотеками України інтернет-маркетингу в науковій літературі на разі не представлено.

Мета статті. Метою публікації є визначення характерних особливостей здійснення інтернет-маркетингу бібліотеками України.

Реалізація мети передбачає вирішення таких дослідницьких завдань:

- окреслення і аналіз теоретичного доробку з проблематики інтернетмаркетингу в діяльності бібліотек України;

- обгрунтування методології і джерельної бази дослідження;

- визначення і висвітлення тих напрямів і інструментів інтернет-маркетингу, які представлені і використовуються в діяльності бібліотек України;

- визначення перспектив вдосконалення реалізації інтернет-маркетингу в діяльності бібліотек України.

\section{МЕТОДИ ТА МАТЕРІАЛИ ДОСЛІДЖЕННЯ.}

В основу дослідження був покладений комплекс наукових методів. Насамперед ефективним виявилось застосування системного методу, який обумовив розгляд окремих видів бібліотечної діяльності, продуктів і послуг із позицій інтернет-маркетингу як системи. Таким чином стало можливим визначення тих напрямів та інструментів інтернет-маркетингу, які сьогодні активно реалізуються та використовуються бібліотеками, і тих, які поки що залишаються поза їхньою увагою і представлені епізодично. Багатий фактографічний матеріал було отримано в результаті використання методу аналізу контенту, зокрема під час аналізу офіційних веб-сайтів та мережевих сторінок бібліотек, у поєднанні з аналізом фахової наукової літератури. Ефективними також виявилися методи включеного спостереження, який дав змогу з позицій користувача оцінити PR-заходи бібліотек та їх зусилля з покращення власного іміджу, моніторингу - щодо вивчення 
Український журнал з бібліотекознавства та інформаційних наук. Випуск 4 (2019) Ukrainian Journal on Library and Information Science. Issue 4 (2019)

організації підтримки функціонування веб-сайтів і мережевих сторінок бібліотек, експерименту - для визначення ефективності бібліотечної контекстної реклами.

Під час дослідження було проаналізовано особливості інтернет-маркетингу передусім тих бібліотек України, політика яких забезпечила видимість цих бібліотек в інтернет-просторі, а також тих, які останнім часом приділяли увагу розробці ефективних маркетингових стратегій, ребрендингу тощо, про що повідомлялось під час професійних форумів, у наукових публікаціях та науково-методичних матеріалах. Відповідно, такий досвід потребує вивчення і поширення. Зокрема, пошук за ключовим словом «бібліотека» в мережі Facebook виявив у порядку появи в результатах посилання на представництво Луганської обласної універсальної наукової бібліотеки, Науково-технічної бібліотеки ім. Г. І. Денисенка Національного технічного університету України «Київський політехнічний інститут імені Ігоря Сікорського», Бібліотеки Національної музичної академії України імені П. І. Чайковського, Наукової бібліотеки Національного університету «Києво-Могилянська академія». Ребрендинг компанією MOSAIC Державної бібліотеки України для юнацтва обумовив включення цієї бібліотеки в джерельну базу дослідження. Крім того, дослідженням було охоплено бібліотеки, які потенційно мають ресурси (фінансові і кадрові) на підтримку маркетингового напряму діяльності, - обласні універсальні наукові бібліотеки, державні та національні бібліотеки України.

\section{ВИКЛАД ОСНОВНОГО МАТЕРІАЛУ.}

Відповідно до структури інтернет-маркетингу, основними його напрямами в діяльності документно-інформаційних установ має стати аналітичний (маркетингові дослідження) - вивчення ринку, користувацького попиту і конкурентів, ефективності продуктів і послуг, комунікаційних зв'язків і маркетингових кампаній; управлінський, який передбачатиме розробку маркетингової стратегії, організацію і підтримку внутрішніх маркетингових процесів; виробничий - розробка і впровадження в практику нових продуктів і послуг та їх сервісне забезпечення (клієнтська підтримка); розподільчий - формування попиту і визначення засобів його підживлення; комунікативний - PR-методи, спрямовані на зміцнення репутаційного та іміджевого потенціалу.

Останнє для бібліотек надзвичайно важливе з огляду на необхідність подолання поширеного стереотипного уявлення про них як про книгозбірні, в яких тихо і порожньо. Через технологічний вибух і поширення технології інтернет, що дає практично необмежений доступ до інформації, багато користувачів реалізовують свої інформаційні запити, оминаючи бібліотеку і звертаючись до альтернативних пошукових систем інтернет-середовища. Тому образ бібліотеки має бути модернізованим. I якщо в реальному житті досягти цього без потужних фінансових вливань доволі складно (адже часто потрібно провести ремонт приміщення, переобладнання установи, осучаснення інтер'єру), то в інтернет-просторі таке завдання цілком можна виконати за наявності управлінської волі.

Як виявив аналіз структури бібліотек і функцій їхніх підрозділів, завдання в межах різних напрямів маркетингу реалізуються переважно різними відділами установ. Підхід, який переважає, - розведення завдань проведення маркетингових досліджень і просування по різних підрозділах. Зазвичай маркетингові дослідження проводить науково-методичний відділ, наявний в усіх національних 
та обласних універсальних наукових бібліотеках, а функція просування покладається на відділи соціокультурної діяльності, прес-служби і т. п. У такий спосіб побудована робота в Національній історичній бібліотеці, Кіровоградській обласній універсальній науковій бібліотеці ім. Д. І. Чижевського, Полтавській обласній універсальній науковій бібліотеці імені І. П. Котляревського, Запорізькій, Дніпропетровській, Житомирській обласних універсальних наукових бібліотеках. В Національній бібліотеці України імені Ярослава Мудрого та Одеській обласній універсальній науковій бібліотеці ім. М. С. Грушевського завдання розподілені в межах трьох підрозділів:

- відділів наукової організації бібліотечних процесів, соціокультурної діяльності та науково-методичного відділу (Національна бібліотека України імені Ярослава Мудрого);

- відділу соціокультурної діяльності, науково-методичного відділу, відділу інформації з питань культури, мистецтва та зв’язків з громадськістю (Одеська обласна універсальна наукова бібліотека ім. М. С. Грушевського).

В деяких бібліотеках соціокультурна діяльність не набула структурного оформлення у вигляді окремого відділу і здійснюється як напрям у роботі інших підрозділів. Закономірно, що розподільчий і комунікативний напрями інтернет-маркетингу в таких установах майже не представлені, останній - переважно у вигляді офіційних веб-сайтів установ.

3 іншого боку, в ряді бібліотечних інституцій маркетингову діяльність оптимізовано в межах одного структурного підрозділу, що відображено в назвах таких відділів: відділ маркетингу, реклами та соціокультурної діяльності (Вінницька обласна універсальна наукова бібліотека ім. К. А. Тімірязєва), відділ маркетингу та наукової роботи (Рівненська обласна універсальна наукова бібліотека), відділ маркетингу і бібліотечної статистики (Миколаївська обласна універсальна наукова бібліотека імені Тараса Шевченка).

Такі підрозділи покликані розробляти методику ефективної діяльності бібліотеки, підходи до максимального задоволення потреб користувачів, здійснювати PR-супровід бібліотечної діяльності, формувати позитивний імідж установи, забезпечувати рекламну та інформаційну підтримку бібліотечних проектів.

Окремі напрями інтернет-маркетингу є добре відомими для працівників бібліотечної сфери. Зокрема вивчення інформаційних потреб користувачів є одним з традиційних завдань, яким у бібліотечній справі традиційно приділяється посилена увага. Т. Коваль взагалі визначає маркетингові дослідження головним чинником оптимізації бібліотечно-інформаційного обслуговування (Коваль, 2012).

Про увагу бібліотек до вивчення користувацьких потреб свідчать також аналітичні звіти і записки, які готуються бібліотеками за результатами проведених досліджень, наявні наукові праці з цього питання (Коновал, 2013; Новальська, 2005; Прокопенко, 2015; Павленко, 2016; Несін, 2011).

Крім вивчення потреб користувачів, послуг і продуктів бібліотек, актуальними є дослідження із різних шляхів просування бібліотечних продуктів і послуг та комунікації з користувачами. Так, наприклад, працівниками Науково-технічної бібліотеки Івано-Франківського національного технічного університету нафти і газу проводилось дослідження ефективності використання соціальних мереж 
Український журнал з бібліотекознавства та інформаційних наук. Випуск 4 (2019) Ukrainian Journal on Library and Information Science. Issue 4 (2019)

у науково-технічній бібліотеці в умовах інформаційного суспільства (Дослідження ефективності використання..., 2016).

Поряд з окремими видами аналітичного напряму інтернет-маркетингу бібліотеками реалізується розподільчий: формування попиту і визначення каналів його підживлення. Насамперед ідеться про ефективне використання рекламних інструментів включно з інструментами просування (різноманітними акціями та бонусними програмами).

Для українських бібліотек одним із найбільш зручних інструментів у просуванні реклами є соціальний медіа-маркетинг, який передбачає використання соціальних медіа. Можливості соціальних мереж із погляду охоплення цільової аудиторії та адресності колосальні. Використовуючи такі соціальні мережі, як Instagram, Twitter, Facebook, бібліотека може як просувати свої продукти та послуги, так і позиціонувати себе як сучасний унікальний заклад, який також надає право на безкоштовне користування інформаційними ресурсами в найбільшому обсязі. Примітним у зв’язку з цим є, наприклад, поява посади SMM-менеджера в Луганській обласній науковій універсальній бібліотеці.

О. Мар'їна розглядає соціальні мережі, «як інструменти бібліотечного маркетингу, що сприяють розповсюдженню бібліотечних новин, стимулюють просування бібліотечних продуктів, послуг та сервісів, анонсують маркетингові заходи, проекти та програми; слугують засобами реклами та PR-технологій для книгозбірень; як “креативне” доповнення основних веб-сайтів бібліотек, що існує паралельно, а подекуди як альтернатива створенняостанніх завдяки доступності (порівняно з оплатою послуг вебмайстра і хостингу)» (Мар’їна, 2012, с.1-2).

На відміну від підтримки офіційного веб-сайту установи, забезпечення функціонування представництва бібліотеки в соціальній мережі не вимагає особливої підготовки бібліотечного працівника, є відносно легким і може здійснюватись поряд з іншими професійними обов'язками. На своїх сторінках у соціальних мережах бібліотеки розміщують анонси подій, організовують онлайн-трансляції, публікують прес-релізи тих заходів, які відбулися, рекламують нові надходження, повідомляють про нові послуги.

Наприклад, Науково-технічна бібліотека ім. Г. І. Денисенка Національного технічного університету України «Київський політехнічний інститут імені Ігоря Сікорського» має власні сторінки в популярних соціальних мережах Facebook, Telegram, Instagram, YouTube, де активно залучає користувачів до різних заходів: виставок, лекцій, семінарів, презентацій книг, зустрічей із письменниками. Розміщує публікації в Instagram, які викликають бажання відвідати бібліотеку та провести час із корисною книгою. Сторінка в Instagram бібліотеки станом на початок вересня 2019 р. налічувала 2 тис. послідовників. У мережі YouTube.com бібліотека завантажує короткі відеозвіти, сюжети про власну діяльність, анонси тощо. Сторінка у Facebook мала близько 5 тис. послідовників, з якими підтримувала активний зворотний зв'язок, щодня публікуючи корисну інформацію, сповіщення про заплановані події та інше.

Національна бібліотека України імені В. I. Вернадського має сторінку в Facebook із кількістю 6 тис. послідовників, де щодня розміщується інформація про події, пам'ятки історії, звіти зустрічей, цікаві факти, і заохочує користувачів до участі у різноманітних заходах, надає інформацію про стажування, робо- 
ту в престижних компаніях. Представлена там інформація $є$ не тільки корисною, а ще і цікавою.

Наукова бібліотека ім. М. Максимовича Київського національного університету імені Тараса Шевченка також $є$ активним користувачем соціальних мереж і має близько 4 тис. послідовників. На своїх сторінках бібліотека приділяє увагу анонсам заходів та подій, які відбудуться найближчим часом, а також звітує перед користувачами про результати різних зустрічей та конкурсів.

Рекламній діяльності бібліотек у соціальних мережах присвячено наукові публікації таких дослідників, як Г. Булахова (Булахова, 2016), О. Мар'їна (Мар'їна, 2012, 2017), М. Самсонов (Самсонов, 2012) та ін.

Ефективною $€$ контекстна або пошукова реклама, яка, щоправда з різним успіхом, використовується різними бібліотеками. Одні з найкращих результатів на разі демонструє портал Національної бібліотеки України імені В. І. Вернадського, матеріали якого практично завжди з'являються в топі (першій десятці) результатів видачі на пошуковий запит за відповідними ключовими словами. Так, наприклад, у результатах пошуку в пошуковій системі Google.com за ключовими словами «електронна доставка документів» або «взяти книгу на абонемент» станом на 2 листопада 2019 р. матеріали порталу НБУВ посідали 7 позицію, поступаючись місцем у першому випадку Бібліотеці Київського університету імені Бориса Грінченка, Херсонській обласній універсальній науковій бібліотеці ім. Олеся Гончара, Одеській обласній універсальній науковій бібліотеці ім. М. С. Грушевського, Науковій бібліотеці Національного університету «Києво-Могилянська академія», Тернопільській обласній універсальній науковій бібліотеці, Науковій бібліотеці Національного педагогічного університету імені М. П. Драгоманова, а в другому - Харківській обласній бібліотеці для дітей. Завдання з просування інформації про бібліотеку та iї матеріалів у пошукових системах вирішує SEO-просування - стратегічно важливий комплекс дій (передусім створення семантичного ядра сайту, забезпечення унікальності контенту), який сприяє підвищенню позицій даного ресурсу в пошуковій видачі по конкретних запитах.

Перші рядки в результатах видачі на запити користувачів спрямовують користувачів пошукових систем інтернет-середовища до бібліотечних ресурсів. У випадку, якщо інформаційна потреба у результаті буде задоволеною, існує доволі висока імовірність, що користувач повертатиметься до веб-порталу бібліотечної установи і згодом може стати зареєстрованим читачем.

Одним з улюблених інструментів інтернет-маркетингу для бібліотеки $є$ відео реклама. Якщо раніше створення відео потребувало спеціального навчання і обладнання, то інтернет-технології, як і у випадку з розміщенням інформації в соціальних мережах, суттєво спростили цей процес. За допомогою смартфонів будь-хто може зняти якісне відео, а численні сервіси інтернету дають можливість його відредагувати відповідно до мети. Так само інтернет-сервіси дають змогу комбінувати різні відео і зображення, а також додавати до них текстові уривки.

Продукуючи різні відео матеріали, багато вітчизняних бібліотек започаткували свої канали на YouTube.com, де розміщують відео матеріали, які поряд з інформаційною функцією виконують, також, рекламну. Сьогодні бібліотеками створюється відео про різноманітні бібліотечні заходи, виставки, саму бібліотеку 
Український журнал з бібліотекознавства та інформаційних наук. Випуск 4 (2019) Ukrainian Journal on Library and Information Science. Issue 4 (2019)

в цілому тощо. Такі відео розміщуються безпосередньо на ресурсі YouTube.com, у соціальних мережах, а також на бібліотечному сайті (див. рис. 1).

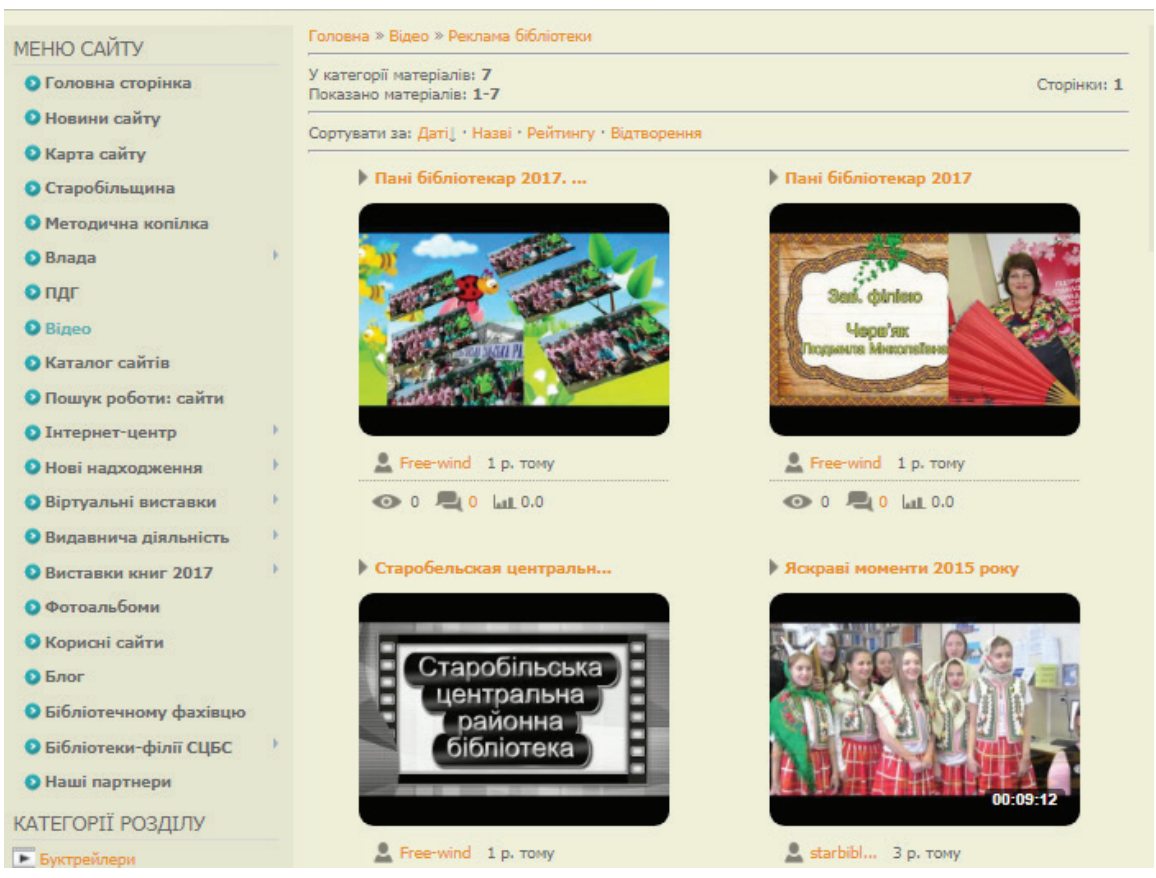

Puc. 1. Відеореклама на сайті Старобільської центральної районної бібліотеки. Джерело: https://bibliost.ucoz.ru/video/vic/reklama_biblioteki.

Мають досвід бібліотеки і у використанні такого ефективного інструменту інтернет-реклами, як прямий маркетинг. Прямий маркетинг часто використовує пряму адресну розсилку повідомлень представникам цільової аудиторії за допомогою e-mail, SMS, оскільки він орієнтується не на цільові групи загалом, а на окремих конкретних особистостей. Проведення заходів прямого маркетингу вимагає створення бази даних користувачів - структурованої, постійно поновлюваної актуальною інформацією про переваги та усвідомлені потреби користувачів із метою подальшого опрацювання цієї інформації та формування на його основі пропозиції продуктів та послуг, яка б відповідала їх запитам. Такі бази даних перебувають у тісному зв’язку з управлінням відносинами із користувачами, що дозволяє зібрати всю інформацію про кожного з них, а також впорядкувати всі стадії взаємовідносин з користувачами від самого початку надання послуги і безпосередньо до клієнтської підтримки вже після використання користувачем запропонованої продукції чи послуги (Кучковський, Висоцька, Нитребич, \& Оливко, 2015, с. 132).

Утім, при всьому великому значенні аналітичного і розподільчого напрямів інтернет-маркетингу суть бібліотечної діяльності представляє його виробничий напрям, а саме розробка і впровадження в практику нових продуктів і послуг та їх сервісне забезпечення. 
Сьогодні інформація про послуги і продукти комплексно представлена на веб-сайтах бібліотек, які, з одного боку, є бібліотечними представництвами в інтернет-просторі, ефективними інструментами комунікації та PR, а 3 іншого комплексними інтегрованими бібліотечними продуктами.

Бібліотечний веб-сайт інформує про події з життя бібліотеки, розповідає про заходи, які вже відбулися, анонсує наступні, за його допомогою користувач може отримати інтернет-послуги бібліотеки і ознайомитись з їі електронними документами, колекціями, базами даних тощо. Вивчення статистики бібліотечного сайту дає змогу зрозуміти, які електронні бібліотечні ресурси і послуги є найбільш затребуваними користувачами i їх варто розвивати, а які потребують модернізації.

Ефективність веб-сайту бібліотеки як їі продукту обумовлюється його змістовністю, інформативністю, актуальністю представленої на сайті інформації, її структурованістю, зручною і зрозумілою навігацією, сучасним дизайном. Додатковою перевагою слугують також передбачені сайтом можливості для зворотного зв’язку - коментарів і запитань.

Слід наголосити, що провідні вітчизняні бібліотеки, такі як Національна бібліотека України імені В. І. Вернадського, Науково-технічна бібліотека ім. Г. І. Денисенка Національного технічного університету України «Київський політехнічний інститут ім. Ігоря Сікорського», Національна бібліотека України імені Ярослава Мудрого та ін., активно здійснюють модернізацію веб-сайтів, розширюють асортимент онлайн-продуктів та послуг, постійно прагнуть до досягнення відповідності сайту вимогам пошукових систем, що дає змогу їм посідати провідні позиції за результатами пошуку інформації користувачами.

Як засвідчив аналіз їхніх сайтів, сьогодні бібліотеками пропонується доволі широкий спектр онлайнових продуктів і послуг. Серед найбільш поширених системи електронних каталогів і тематично-видових баз даних, електронні каталоги, які об'єднують електронні каталоги книжкових видань і електронні каталоги журналів та продовжуваних видань, реферативні бази даних, імідж-каталоги спеціалізованих підрозділів, електронні каталоги і тематично-видові бази даних спеціалізованих підрозділів, тематичні електронні виставки, екскурсії, огляди, спілкування онлайн, доступ до наукової періодики, електронна доставка та замовлення документів, доступ до електронних архівів, колекцій, пошук документів та інформаційних ресурсів, доступ до бібліографічних ресурсів, інформаційно-аналітичних видань, можливість отримання довідково-консультаційної інформації, довідково-бібліографічне обслуговування, адресна розсилка інформації про нові надходження книжкових та періодичних видань до фондів, виготовлення документів шляхом сканування або іншої комп’ютерної обробки документів у електронному вигляді та надсилання копій замовнику.

Найбільш комплексно аналіз тих онлайнових продуктів і послуг, які сьогодні надаються бібліотеками, представлений у вітчизняному бібліотекознавстві у монографічних дослідженнях О. Мар'їною (Мар'їна, 2017) та В. Бондаренко (Бондаренко, 2016). Зокрема, значна увага приділяється створенню електронних бібліотек, електронних каталогів як окремих бібліотечних інституцій, так і корпоративних проектів, що реалізуються спільно різними бібліотеками на локальному, регіональному, національному та світовому рівнях; просуванню бібліоте- 
Український журнал з бібліотекознавства та інформаційних наук. Випуск 4 (2019) Ukrainian Journal on Library and Information Science. Issue 4 (2019)

ками ініціативи відкритого доступу до інформації, зокрема шляхом формування і підтримки функціонування інституційних репозитаріїв; розвитку сервісів електронної доставки документів та «віртуальної довідки», організації віртуальних виставок; комплексу продуктів і послуг зі сприяння функціонуванню системи «електронного урядування»; бібліотечним інформаційно-аналітичним продуктам як інструменту відбору та збереження інформації інтернет-середовища тощо. У монографіях також представлені актуальні класифікації сучасних продуктів і послуг бібліотек, що надаються за допомогою інтернет-технологій.

Як зазначає О. Мар'їна, наразі «найбільшого поширення набули традиційні інформаційні продукти і послуги бібліотек, “перенесені” у цифровий простір без змін, так звані “цифрові копії”. Менш розповсюдженими є традиційні, трансформовані у відповідності до вимог цифрового медіапростору або цифрові аналоги, “запозичені електронним середовищем”. Найбільш перспективною, але досі нечисленною $є$ інноваційна бібліотечна продукція, яка отримала свій початок безпосередньо в електронному технологічному медіасередовищі» (Мар'їна, 2017, c. $117-118)$.

Подібного висновку доходить і В. Бондаренко, за спостереженням якої «для провідних бібліотек України наразі характерним є здійснення інтернетобслуговування шляхом надання окремих послуг із використанням електронної пошти та на основі функціонування веб-сайтів. Комплексне використання широкого спектра інтернет-послуг на основі бібліотечного веб-сайту, електронної пошти, сервісу скайпу (Skype) та віртуальних соціальних мереж у вітчизняній бібліотечній практиці є поки що винятком» (Бондаренко, 2016, с. 52-53).

Останній, але від того не менш важливий напрям бібліотечного інтернетмаркетингу - комунікативний, спрямований серед іншого на встановлення ефективного взаємозв’язку між бібліотекою та користувачами, формування сучасного позитивного іміджу установи.

Як наголошують експерти Української бібліотечної асоціації, PR або зв’язки з громадськістю (від англ. PR - public relations) означають поточні заходи щодо забезпечення позитивного іміджу бібліотеки та ї̈ вагомої ролі для громади (Сучасні інструменти бібліотечної реклами..., 2012). Утім значення PR не лише у формуванні іміджу, а і в побудові репутації і бренду. Репутацію тут можна визначити як сталість іміджу в часі, тобто усталені уявлення про функціонування як окремої установи, так і інституту бібліотеки в цілому. Сформувати перше враження від установи в інтернет-просторі можливо, створивши сучасний сайт, розробивши логотип тощо. Утім вибудовування репутації потребує більших зусиль і більш тривалого часу і напряму залежить від поведінкової практики установи, того, наскільки сучасними і якісними є її продукти і послуги, наскільки клієнтоорієнтованим і компетентним є персонал, наскільки інформація про діяльність бібліотеки вчасно доходить до широкого загалу, якими шляхами тощо. Імідж, помножений на репутацію, посилює позиції бібліотеки на ринку інформації, у підсумку чого стає можливим формування бренду. За висновком Г. Булахової, «виходячи з ринкової логіки, за якою прибуток можуть приносити не тільки товари і послуги, а й нематеріальні активи, конвертування позитивного іміджу в доходи різного роду дає змогу говорити про бренд як конкурентну ідентичність, суму всіх матеріальних і символічних елементів, які роблять бібліотеку унікальною, 
власне, її комерціалізований імідж. Більше того, у випадку з брендингом ідеться не просто про багатовимірний конструкт, функціональні, емоційні й матеріальні елементи якого в сукупності створюють унікальний набір асоціацій у суспільній свідомості, а і про цілеспрямоване формування цих асоціацій» (Булахова, 2017, c. 316).

PR передбачає відкритість установи для реакції користувачів. Підтримка такої відкритості $є$ необхідною умовою для того, щоб установа трансформувалася відповідно до очікувань і потреб користувацької аудиторії. PR спрямований на досягнення згоди між користувачами і бібліотекою як суб'єктами інформаційних відносин, його дія має двосторонню спрямованість: з одного боку, бібліотека інформує про свою діяльність, перспективи модернізації, пояснює особливості функціонування, з іншого - користувачі своєю поведінкою демонструють рівень задоволення бібліотечним сервісом, повідомляють про свої потреби і очікування.

Сьогодні окремими бібліотеками приділяється серйозна увага організації PR-заходів і покращенню власного іміджу. Ілюстративні приклади - увага до іміджу і репутації працівників Наукової бібліотеки Національного університету «Києво-Могилянська академія», кампанії зі створення оновленого іміджу Науково-технічної бібліотеки ім. Г. І. Денисенка Національного технічного університету України «Київський політехнічний інститут імені Ігоря Сікорського», Луганської обласної універсальної наукової бібліотеки, Державної бібліотеки України для юнацтва, зміна назви колишньої Національної парламентської бібліотеки України на Національну бібліотеку України імені Ярослава Мудрого та ін.

Бібліотеками було розроблено логотипи, визначено корпоративні кольори, які присутні як в інтернет-представництвах установ (на офіційних сайтах та сторінках у соціальних мережах), так і в рекламній продукції - буклетах, матеріалах конференцій, блокнотах, плакатах, презентаціях тощо. Образ бібліотек став упізнаваний, їхні матеріали в мережі легко ідентифікувати (див. рис. 2).
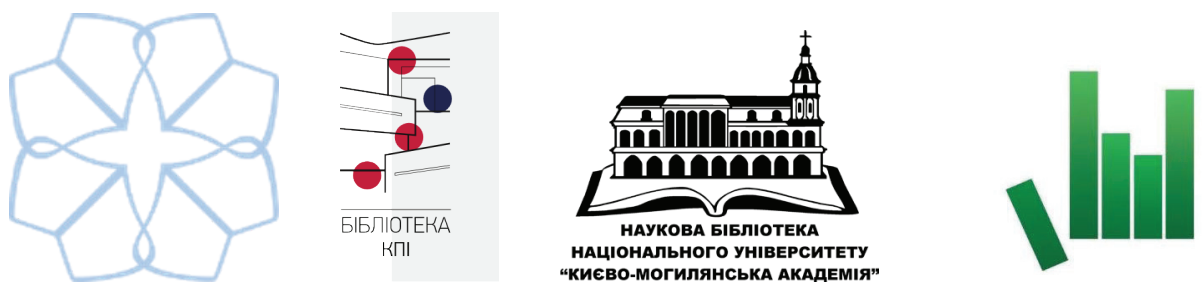

Puc. 2. Логотипи зліва направо Луганської обласної універсальної наукової бібліотеки, Науково-технічної бібліотеки ім. Г. І. Денисенка Національного технічного університету

України «Київський політехнічний інститут імені Ігоря Сікорського»,

Наукової бібліотеки Національного університету «Києво-Могилянська академія», Державної бібліотеки України для юнацтва.

Джерела: http://ibrary.lg.ua/; https://www.library.kpi.ua; http://ekmair.ukma.edu.ua/ handle/123456789/1449; http://www.4uth.gov.ua.

Ефективний логотип сприяє популярності установи в інтернеті, адже в мережі інтернет доступ до продуктів і ресурсів бібліотеки отримують не лише її адресні користувачі, а й ті, хто потрапив на них випадково, візуально приваблений лого- 
типом. У випадку підкріплення першої викликаної логотипом позитивної реакції через задоволення інформаційної потреби внаслідок користування ресурсом такі користувачі можуть стати постійними читачами бібліотеки.

Для прикладу порівняємо логотипи Державної бібліотеки для юнацтва і Київської обласної бібліотеки для юнацтва (див. рис. 3):
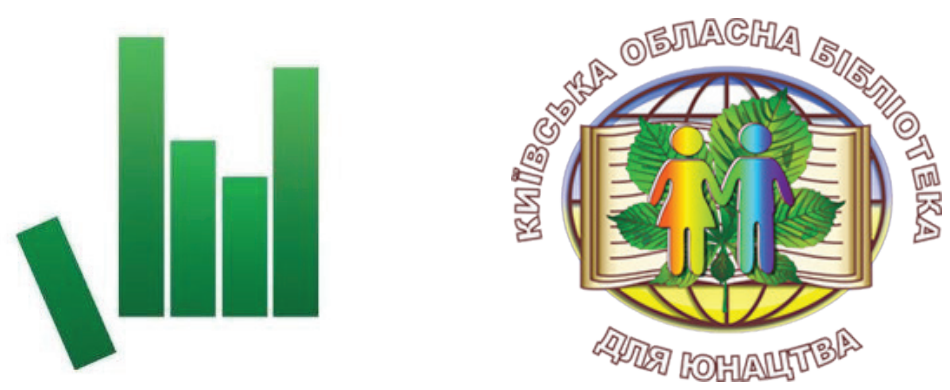

Puc. 3. Логотипи зліва направо Державної бібліотеки України для юнацтва, Київської обласної бібліотеки для юнацтва.

Джерела: http://www.4uth.gov.ua; http://www.kobu.kiev.ua.

Цільова аудиторія обох бібліотек - одна, але візуальні образи установ, відображені в їх логотипах, істотно відрізняються. У першому випадку - це сучасний логотип, який одразу приверне увагу молоді, адже він відповідає і завданню бібліотеки, і сучасним молодіжним трендам. Із таким логотипом установа сприймається молоддю «своєю». 3 іншого боку, логотип Київської обласної бібліотеки для юнацтва повертає в часи Радянського Союзу, і може привернути увагу швидше старшого покоління, а не молоді. Звичайно, логотип доносить основні цінності бібліотеки, а листя каштану символізує Київ, проте традиційна стилістика формує уявлення, що самому приміщенню та інформації, наявній у бібліотеці, також бракує актуальності.

Логотип і корпоративні кольори є компонентами корпоративного стилю бібліотеки, до яких може додаватися і слоган (гасло), фірмовий шрифт або набір шрифтів.

Важливим є дотримання корпоративного стилю бібліотеки її інтернет-представництвами. Насамперед - веб-сайтом. Це забезпечить впізнаваність ресурсу, продуктів і послуг бібліотеки.

Крім візуального компонента, іміджеве і репутаційне навантаження в комунікації містить також вербальний компонент, а саме - про що і як розповідає бібліотека. Про розуміння бібліотеками цього напряму роботи свідчить поява такого напряму підготовки і підвищення кваліфікації бібліотечних фахівців, як бібліотечна журналістика.

Як ідеться в робочій програмі з відповідної навчальної дисципліни, що викладається на кафедрі бібліотекознавства та інформології Київського університету імені Бориса Грінченка, метою бібліотечної журналістики є «ознайомлення студентів із системою мас-медіа та взаємодії бібліотечної структури зі 3МI, засвоєння учасниками методів, прийомів, засобів журналістської діяльності та отримання практичних навичок, сприяння професійному розвитку майбутніх бі- 
бліотекарів для створення позитивного іміджу бібліотек через співпрацю зі 3МІ різного рівня, бібліотечні 3МI (електронні та друковані), сайти, блоги» (Поліщук, 2018).

У 2013 р. за ініціативи заступника директора з наукової роботи Харківської державної наукової бібліотеки (ХДНБ) ім. В. Г. Короленка Л. Глазунової на базі бібліотеки за грантової підтримки програми «Бібліоміст» IREX/Україна, інформаційного партнерства НВП «Ідея» та журналу «Бібліотечний форум України» було започатковано навчально-інноваційний проект із бібліотечної журналістики - Школу бібліотечного журналіста, випускники якої отримують відповідні сертифікати.

Неформальні, доступні до сприйняття широкого загалу, щирі тексти-історії покликані сприяти приверненню позитивної уваги до бібліотеки та її персоналу, їх позиціонуванню як зрозумілих, доступних, відкритих для широкого загалу. Яскравий приклад надає Луганська обласна універсальна наукова бібліотека, на офіційному сайті якої в розділі «Про бібліотеку» читаємо:

«Привіт, ми Good library! А ще нас кличуть Луганською обласною універсальною науковою бібліотекою....

...Good library - це новосформована креативна і божевільна команда. Окрім бібліотекарів, у нас працюють люди творчих професій: дизайнер, письменники/ ці, програміст, інженер та аналітики.

У нас одне приміщення. Воно невеличке, але комфортне і вміщує до 100 осіб. ... У ньому відбувається все: кінопокази, семінари, лекції, форуми, мітапи. До нас приходять із планшетами й ноутбуками, щоб попрацювати за просторими столами у теплому й добре освітлюваному приміщенні.

Проводимо Літературний БУМ - неформальні збори всіх, хто любить читати, щось писати, говорити або розважатися. Щотижня діє CodeClub - клуб програмування для дітей $8-13$ років. Там діти вчаться програмувати за 4 рівнями складності....

Відкриті до будь-яких ідей і пропозицій завжди. Але ми безсилі, якщо ви не хочете змін.

Наша місія - зламати застарілу систему бібліотечної справи, зруйнувати назавжди незграбні штампи щодо бібліотек, привернути увагу молоді, експериментувати на кожному кроці» (Про бібліотеку, 2019).

На користь «зламу» стереотипів і шаблонів, ребрендингу установи свідчать і нові формати заходів, які пропонуються нею користувачам, - антилекції, CodeClub, літературний БУМ тощо.

Аналіз контенту бібліотечних веб-сайтів і офіційних сторінок у соціальних мережах виявив, що серед бібліотек, що намагаються комунікувати з користувачем його мовою і пропонують нові формати взаємодії, - Науково-технічна бібліотека ім. Г. І. Денисенка Національного технічного університету України «Київський політехнічний інститут імені Ігоря Сікорського», Харківська державна наукова бібліотека ім. В. Г. Короленка, Хмельницька обласна бібліотека для юнацтва, Херсонська обласна бібліотека для юнацтва ім. Б. Лавреньова, Наукова бібліотека ім. М. Максимовича Київського національного університету імені Тараса Шевченка та ін.

Подібна модернізація діяльності позитивно впливає на формування сучасного іміджу бібліотек, адже чим більше різноманітних подій відбуватиметься, тим 
Український журнал з бібліотекознавства та інформаційних наук. Випуск 4 (2019) Ukrainian Journal on Library and Information Science. Issue 4 (2019)

більш змістовними ставатимуть бібліотечні публікації в соціальних мережах та на веб-сайтах, через які користувачі отримуватимуть цікаву і корисну інформацію. Проведення неординарних заходів і реалізація інноваційних проектів сприятиме також приверненню уваги 3MI, які є одним із найважливіших каналів комунікації для бібліотек. Саме 3МІ дають вихід на найбільш масову аудиторію. Тож для бібліотек актуальною є співпраця зі 3МI, залучення їх до висвітлення бібліотечних подій.

Налагодження партнерського діалогу з користувачем, як із рівним, без намагання повчати його, організація тих заходів, які відповідають інтересам користувачів, допомагають у підсумку донести до громадськості розуміння місії і цінностей бібліотеки, вирішують завдання як розвитку громади, так і розвитку бібліотеки.

\section{ВИСНОВКИ.}

Як засвідчив аналіз бібліотечної діяльності, на сьогодні бібліотеками України використовуються лише деякі інструменти інтернет-маркетингу в рамках реалізації окремих напрямів маркетингової діяльності. Основними онлайновими маркетинговими комунікаціями, які сьогодні використовуються бібліотеками України, $є$ бібліотечні сайти, представництва бібліотек в соціальних мережах, меншою мірою онлайнові і традиційні 3МІ. За допомогою масмедіа бібліотеками проводяться кампанії з ребрендингу, оновлення іміджу установ, донесення до користувачів інформації стосовно модернізації бібліотечно-інформаційного сервісу надання поряд із традиційними для бібліотек продуктами і послугами доступу до онлайнового сервісу та інноваційних інтерактивних заходів.

Разом із тим, комплексне стратегічне бачення бажаного результату, короткострокових і довгострокових цілей, розуміння взаємозв'язку і взаємовпливів елементів системи інструментів і дій, спрямованих на їх досягнення, може розширити можливості бібліотек на інформаційному ринку, зміцнюючи їх статус і сприяючи розвитку навколишньої спільноти.

Передусім розвитку потребує аналітичний напрям бібліотечної діяльності. Поряд із вивченням аудиторії користувачів, яке періодично проводиться бібліотеками, така сама увага має приділятися також вивченню конкурентів і ринку, який динамічно розвивається. На інформаційному ринку сьогодні з'являються приватні бібліотеки, бібліокав’ярні, книжкові стартапи, які успішно конкурують із бібліотеками, тож вивчення їх переваг дасть змогу зробити відповідні висновки щодо того, який досвід краще перейняти і які помилки не варто повторювати. Дослідження конкурентного середовища важливі й з огляду на необхідність зберігати конкурентоздатність, аргументувати власну затребуваність і забезпечувати фінансування. До того ж вивчення конкурентного середовища і ринку є одним із джерел для розробки і впровадження інновацій.

Крім того, в рамках аналітичного напряму важливим $є$ вивчення ефективності функціонування різних інструментів інтернет-маркетингу та реалізації його різних напрямів. Зокрема, потребує осмислення затребуваність наявних продуктів і послуг у бібліотеках, адже результати дослідження дадуть змогу оптимізувати структуру бібліотеки та перерозподілити кадрові ресурси. Також в умовах обмеженого фінансування варто звертати увагу на співвідношення трудозатрат і результату під час розробки нових продуктів або послуг. 
Посиленої уваги з боку бібліотек потребує також управлінський напрям інтернет-маркетингу. Передусім доцільною є розробка виваженої маркетингової стратегії в інтернет-середовищі і організація відповідно до неї внутрішніх маркетингових процесів. Перш ніж розробляти нові продукти і послуги, багато з яких може потребувати додаткових фінансових надходжень і витрат часу, просувати їх в інтернет-середовищі, важливо розуміти, наскільки саме ці послуги і продукти $є$ затребуваними користувачами. Перш ніж проводити модернізацію іміджу бібліотеки, важливо розуміти, наскільки органічно буде сприйнято новий імідж цільовою аудиторією установи.

На відміну від звичайного планування, маркетингова стратегія орієнтується не на бачення самих бібліотечних працівників того, якою має бути бібліотека, які саме послуги і які продукти вона має надавати користувачам, а на дані проведених маркетингових досліджень, користувацькі потреби та очікування, які спонукають бібліотеку до вдосконалення технологічних процесів, перенавчання персоналу, реструктуризації, впровадження інновацій. Розробка ефективної маркетингової стратегії в умовах недостатнього фінансування сприятиме оптимізації використання наявних фінансових і людських ресурсів, а також визначенню пріоритетних для бібліотеки завдань та послідовності їх реалізації.

\section{СПИСОК ПОСИЛАНЬ}

Акулич М. Видеомаркетинг в Интернете. Издательские решения, 2019. 68 с.

Акулич М. Интернет-маркетинг. Политики маркетинга. Интернет-аукционы. Торговые интернет-площадки и торговля. Издательские решения, 2017. 140 с.

Бондаренко В. І. Бібліотечне інтернет-обслуговування: стан та преспективи : монографія. 2016. Київ : НБУВ. 273 с.

Булахова Г. Рекламна стратегія просування продуктів і послуг бібліотек у соціальній мережі Facebook. Наукові праці Національної бібліотеки України ім. В. І. Вернадського. 2016. Вип. 43. С. 331-345.

Булахова Г. Фотоімідж бібліотеки в інтерактивному просторі. Наукові праці Національної бібліотеки України ім. В. І. Вернадського. 2017. Вип. 46. С. 313-328.

Гранчак Т. Ю. Використання національними бібліотеками соцмереж для представлення бібліотечних продуктів і послуг. Бібл. вісн. 2016. № 1. С. 18-29.

Дослідження ефективності використання соціальних мереж у науково-технічній бібліотеці в умовах інформаційного суспільства / підгот. Ю. В. Кобітович. Івано-Франківськ: НТБ ІФНТУНГ, 2016. 14 с.

Кеннеди Д., Филлипс У. Жесткий SMM. Выжать из соцсетей максимум / пер. с англ. П. Миронов. Москва: ООО «Альпина Паблишер», 2017. 380 с.

Коваль Т. Маркетингові дослідження - головний чинник оптимізації бібліотечно-інформаційного обслуговування. Вісник Львівського університету. Серія: Книгознавство, бібліотекознавство та інформаційні технології. 2012. Вип. 7. С. 182-188.

Коновал Л. В. Методи дослідження користувачів бібліотеки та їх інформаційних потреб. Міжнародна наукова конференція «Адаптація завдань і функцій наукової бібліотеки до вимог розвитку цифрових інформаційних ресурсів». 2013. URL: http://conference.nbuv.gov.ua/report/view/id/177 (дата звернення: 11.08.2019).

Кучковський В. В., Висоцька В. А., Нитребич С. З., Оливко Р. М. Застосування методів інтернет-маркетингу для аналізу web-ресурсів в межах регіону. Вісник Національ- 
Український журнал з бібліотекознавства та інформаційних наук. Випуск 4 (2019) Ukrainian Journal on Library and Information Science. Issue 4 (2019)

ного університету «Львівська політехніка». Інформаційні системи та мережі. 2015. № 832. С. 129-164.

Мар'їна О. Ю. Бібліотека в цифровому просторі : монографія. Харків : ХДАК, 2017. 326 с.

Мар'їна О. Ю. Бібліотеки та соціальні медіа: технологія взаємодії. Вісник Книжкової палати. 2012. № 8. С. $1-3$.

Несін В. Інформаційні потреби користувачів сільських бібліотек та шляхи їхнього задоволення. Наукові праці Національної бібліотеки України ім. В. І. Вернадського. 2011. Вип. 32. С. 341-348.

Новальська Т. Український читач у бібліотекознавчих дослідженнях (кінець XIX - початок XXI ст.) : монографія. Київ, 2005. 459 с.

Павленко Т. С. Інформаційні потреби користувачів - орієнтир удосконалення бібліотечної діяльності. Наукові праці Державної науково-педагогічної бібліотеки України імені В. О. Сухомлинського. 2016. Вип. 5. С. 120-128.

Поліщук Т. І. Робоча програма навчальної дисципліни «Бібліотечна журналістика». Київ, 2018. URL: http://elibrary.kubg.edu.ua/id/eprint/24768/1/T_Polishchuk_BJ.pdf (дата звернення: 11.08.2019).

Про бібліотеку. Луганська обласна універсальна наукова бібліотека. 2019. URL: http://library. lg.ua/uk/pearl/about\# (дата звернення: 11.08.2019).

Прокопенко Л. І. Інформаційні потреби користувачів обласних універсальних наукових бібліотек України : монографія. Київ : Вид-во Ліра-К, 2015. 220 с.

Ростовцев С. Формування системи інтернет-маркетингу в бібліотеках України. Вісник Книжкової палати. 2017. № 6. С. 8-12.

Самсонов М. Реклама бібліотек в онлайнових соціальних мережах. Наукові праці Національної бібліотеки України ім. В. І. Вернадського. 2012. Вип. 33. С. 532-542.

Струнгар В. Бібліотека і соціальні медіа: термінологічно-понятійний аспект. Бібл. вісн. 2014. № 6. С. 23-27.

Сучасні інструменти бібліотечної реклами і маркетингу. Бібліоміст. У скарбницю бібліотекарю. 2012. URL: https://gurt.org.ua/uploads/news/2012/12/27/skarbnycia_11.pdf (дата звернення: 11.08.2019).

Тарасевич А. А. Продвижение библиотек в социальных сетях. Библиотечный дискурс. 2016. Вип. 1. С. 129-138.

Успенский И. В. Интернет-маркетинг. 2003. СПб.: Изд-во СПГУЭиФ. URL: http://www.aup. $\mathrm{ru}$ /books/m80/ (дата звернення: 11.08.2019).

Філіпова Л. Аналіз контенту веб-сайтів українських центрів науково-технічної інформації з точки зору використання інтернет-сервісів. Вісник Книжкової палати. 2012. № 10. C. 1-6.

Ханан И., Голик В. С. Marketing And Internet Marketing. Менеджмент и маркетинг: опыт и проблемы : сб. науч. тр. / [под общ. ред. И. Л. Акулича] ; Белорус. гос. экон. ун-т [и др.]. Минск : А. Н. Вараксин, 2018. С. 244-247.

Aloysius D.A., Awa P.C., Aquaisua A.O. E-Marketing of Library Resources and Patronage by Students in University Libraries of AkwaIbom State, Nigeria. Library Philosophy and Practice. 2019. Vol. 1, № 5. URL: http://cird.online/ESSAJ/index.php/2019/06/08/e-marketing-oflibrary-resources-and-patronage-by-students-in-university-libraries-of-akwa-ibomstate-nigeria/ (accessed: 12.10.2019).

Bhatia P. Fundamentals of Digital Marketing. 2nd ed. Pearson, 2019. 512 p.

Bly R. The Digital Marketing Handbook. Entrepreneur Press, 2018. 330 p.

Bren B. Facebook Marketing Step-by-Step: The Guide To Facebook Advertising That Will Teach You How To Sell Anything Through Facebook - Learn How To Develop A Strategy And Grow Your Business. Amazon Digital Services LLC, 2019. 167 p. 
Casey M., Savastinuk L. We Know What Library 2.0 Isand Is Not. Library Crunch. 2007. URL: http:// www.librarycrunch.com/2007/10/we_know_what_library_20_is_and.html

(accessed: 12.10.2019).

Chaffey D., Ellis-Chadwick F. Digital Marketing. 7th ed. Pearson, 2019.576 p.

Charlesworth A. Digital Marketing: A Practical Approach. 3rd ed. Routledge, 2018. 353 p.

Helsen K. Digital marketing in the global marketplace: Latest developments. 2019. URL: http://repository.ust.hk/ir/bitstream/1783.1-98195/1/22-MKHEL-2903.pdf ～(accessed: 02.11.2019).

Kaur P., Pathak A., Kaur K. E-Marketing - A Global Perspective. Journal of Engineering Research and Applications. 2015, Vol. 5, Iss. 2. P.116-124.

Maness J. M. Library 2.0 Theory: Web 2.0 and Its Implications for Libraries. URL: http://www. webology.org/2006/v3n2/a25.html (accessed: 12.10.2019).

Stokes R. eMarketing: The essential guide to marketing in a digital world. Quirk eMarketing (Pty) Ltd. 5th ed. Red \& Yellow, 2014. 589 p.

Zaveri B. N., Amin P. D. Global Marketing Strategy in Digital Era: Global Online Presence. Breaking Down Language and Cultural Barriers Through Contemporary Global Marketing Strategies / Ed. M. Khosrow-Pour.IGI Global, 2019. P.103-112.

\section{REFERENCES}

Akulich, M. (2019). Videomarketing v Internete [Online Video Marketing]. Izdatelskie resheniya [in Russian].

Akulich, M. (2017). Internet-marketing. Politiki marketinga. Internet-auktsiony. Torgovyie internetploschadki i torgovlya [Internet Marketing. Marketing Policies. Online auctions. Online Trading]. Izdatelskie resheniya [in Russian].

Bondarenko, V.I. (2016). Bibliotechne internet-obsluhovuvannia: stan ta prespektyvy [Library Internet Services: Status and Perspectives] [Monograph]. Kyiv: NBUV [in Ukrainian].

Bulakhova, H. (2016). Reklamna stratehiia prosuvannia produktiv i posluh bibliotek u sotsialnii merezhi Facebook [Advertising Strategy for Promoting Library Products and Services on Facebook Social Network]. Naukovi pratsi Natsionalnoi biblioteky Ukrainy im. V. I. Vernadskoho, 43, 331-345 [in Ukrainian].

Bulakhova, H. (2017). Fotoimidzh biblioteky v interaktyvnomu prostori [Photo image of the library in the interactive space]. Naukovi pratsi Natsionalnoi biblioteky Ukrainy im. V. I. Vernadskoho, 46, 313-328 [in Ukrainian].

Hranchak, T.Yu. (2016). Vykorystannia natsionalnymy bibliotekamy sotsmerezh dlia predstavlennia bibliotechnykh produktiv i posluh [Usage Social Networks Among National Libraries for Presentation of Library Products and Services]. Bibliotechnyi visnyk, 1, 18-29 [in Ukrainian].

Kobitovych, Yu.V. (Comp.). (2016). Doslidzhennia efektyvnosti vykorystannia sotsialnykh merezh $u$ naukovo-tekhnichnii bibliotetsi $v$ umovakh informatsiinoho suspilstva [Research of the Efficiency of Using Social Networks in the Scientific and Technical Library in the Conditions of Information Society]. Ivano-Frankivsk: NTB IFNTUNH [in Ukrainian].

Kennedi, D., \& Fillips, U. (2017). Zhestkiy SMM. Vyizhat iz sotssetey maksimum [Hard SMM. Squeeze Maximum from Social Networks] (P. Mironov, Trans.). Moscow: OOO "Alpina Pablisher" [in Russian].

Koval, T. (2012). Marketynhovi doslidzhennia - holovnyi chynnyk optymizatsii bibliotechnoinformatsiinoho obsluhovuvannia [Marketing Research is a Major Factor in Optimizing Library and Information Services]. Visnyk Lvivskoho universytetu. Seriia: Knyhoznavstvo, bibliotekoznavstvo ta informatsiini tekhnolohii, 7, 182-188 [in Ukrainian]. 
Konoval, L.V. (2013). Metody doslidzhennia korystuvachiv biblioteky ta yikh informatsiinykh potreb [Methods of Researching Library Users and Their Information Needs]. In Adaptatsiia zavdan i funktsii naukovoi biblioteky do vymoh rozvytku tsyfrovykh informatsiinykh resursiv [Adaptation of tasks and functions of the scientific library to the requirements of development of digital information resources], Proceedings of the International Conference. Retrieved from http://conference.nbuv.gov.ua/report/view/id/177 [in Ukrainian].

Kuchkovskyi, V.V., Vysotska, V.A., Nytrebych, S.Z., \& Olyvko, R.M. (2015). Zastosuvannia metodiv internet-marketynhu dlia analizu web-resursiv v mezhakh rehionu [Application of Internet Marketing Methods for the Analysis of Web-Resources within the Region]. Visnyk Natsionalnoho universytetu "Lvivska politekhnika". Informatsiini systemy ta merezhi, 832, 129-164 [in Ukrainian].

Mar'ina, O.Yu. (2017). Biblioteka v tsyfrovomu prostori [The Library in the Digital Space][Monograph]. Kharkiv: KhDAK [in Ukrainian].

Mar'ina, O.Yu. (2012). Biblioteky ta sotsialni media: tekhnolohiia vzaiemodii [Libraries and Social Media: Technology of Interaction]. Bulletin of the Book Chamber, 8, 1-3 [in Ukrainian].

Nesin, V. (2011). Informatsiini potreby korystuvachiv silskykh bibliotek ta shliakhy yikhnoho zadovolennia [Information Needs of Rural Library Users and Ways to Meet Them]. Naukovi pratsi Natsionalnoi biblioteky Ukrainy im. V. I. Vernadskoho, 32, 341-348 [in Ukrainian].

Novalska, T. (2005). Ukrainskyi chytach u bibliotekoznavchykh doslidzhenniakh (kinets XIX pochatok XXI st.) [Ukrainian Reader in Library Studies (End of XIX - the Beginning of XXI Centuries)] [Monograph]. Kyiv [in Ukrainian].

Pavlenko, T.S. (2016). Informatsiini potreby korystuvachiv - oriientyr udoskonalennia bibliotechnoi diialnosti [Information Needs of Users is a Benchmark for Improving Library Activity]. Naukovi pratsi Derzhavnoi naukovo-pedahohichnoi biblioteky Ukrainy imeni V. O. Sukhomlynskoho, 5, 120-128 [in Ukrainian].

Polishchuk, T.I. (2018). Robocha prohrama navchalnoi dystsypliny "Bibliotechna zhurnalistyka" [Work Program of the Discipline "Library Journalism"]. Kyiv. Retrieved from http://elibrary.kubg.edu.ua/id/eprint/24768/1/T_Polishchuk_BJ.pdf [in Ukrainian].

Luhanska oblasna universalna naukova biblioteka (2019). Pro biblioteku [About the Library]. Retrieved from http://library.lg.ua/uk/pearl/about\# [in Ukrainian].

Prokopenko, L.I. (2015). Informatsiini potreby korystuvachiv oblasnykh universalnykh naukovykh bibliotek Ukrainy [Information Needs of Users of Regional Universal Scientific Libraries of Ukraine] [Monograph]. Kyiv: Vydavnytstvo Lira-K [in Ukrainian].

Rostovtsev, S. (2017). Formuvannia systemy internet-marketynhu v bibliotekakh Ukrainy [Formation of Internet Marketing System in Libraries of Ukraine]. Bulletin of the Book Chamber, 6, 8-12 [in Ukrainian].

Samsonov, M. (2012). Reklama bibliotek v onlainovykh sotsialnykh merezhakh [Advertising of Libraries in Online Social Networks]. Naukovi pratsi Natsionalnoi biblioteky Ukrainy im. V. I. Vernadskoho, 33, 532-542 [in Ukrainian].

Strunhar, V. (2014). Biblioteka i sotsialni media: terminolohichno-poniatiinyi aspekt [Library and Social Media: A Terminological-Conceptual Aspect]. Bibliotechnyi visnyk, 6, 23-27 [in Ukrainian].

Suchasni instrumenty bibliotechnoi reklamy i marketynhu [Modern Library Advertising and Marketing Tools]. (2012). Bibliomist. U skarbnytsiu bibliotekariu. Retrieved from https:// gurt.org.ua/uploads/news/2012/12/27/skarbnycia_11.pdf [in Ukrainian].

Tarasevich, A.A. (2016). Prodvizhenie bibliotek v sotsialnyih setyah. [Promotion of Libraries in Social Networks]. Bibliotechnyiy diskurs, 1, 129-138 [in Russian].

Uspenskiy, I.V. (2003). Internet-marketing [Internet Marketing]. St. Petersburg: Izdatelstvo SPGUEiF. Retrieved from http://www.aup.ru/books/m80/ [in Russian].

Filipova, L. (2012). Analiz kontentu veb-saitiv ukrainskykh tsentriv naukovo-tekhnichnoi informatsii z tochky zoru vykorystannia internet-servisiv [Content Analysis of Web-sites 
of Ukrainian Centers of Scientific and Technical Information in Terms of Use of Internet Services]. Bulletin of the Book Chamber, 10, 1-6 [in Ukrainian].

Hanan, I., Golik, V.S. (2018). Marketing and Internet Marketing [Marketing and Internet Marketing]. In I. L. Akulich (Ed.), Menedzhment i marketing: opyt i problemy [Management and marketing: experience and problems] (pp. 244-247). Minsk: A. N. Varaksin [in Russian].

Aloysius, D.A., Awa, P.C., Aquaisua, A.O. (2019). E-Marketing of Library Resources and Patronage by Students in University Libraries of AkwaIbom State, Nigeria. Library Philosophy and Practice, 1(5). Retrieved from http://cird.online/ESSAJ/index.php/2019/06/08/e-marketing-of-library-resources-and-patronage-by-students-in-university-libraries-of-akwaibom-state-nigeria/ [in English].

Bhatia, P. (2019). Fundamentals of Digital Marketing. (2nd ed.). Pearson [in English].

Bly, R. (2018). The Digital Marketing Handbook. Entrepreneur Press [in English].

Bren, B. (2019). Facebook Marketing Step-by-Step: The Guide To Facebook Advertising That Will Teach You How To Sell Anything Through Facebook - Learn How To Develop A Strategy And Grow Your Business. Amazon Digital Services LLC [in English].

Casey, M., Savastinuk, L. (2017). We Know What Library 2.0 Is and Is Not. Library Crunch. 2007. Retrieved from http://www.librarycrunch.com/2007/10/we_know_what_library_20_is_ and.html [in English].

Chaffey, D., \& Ellis-Chadwick, F. (2019). Digital Marketing. (7th ed.). Pearson [in English].

Charlesworth, A. (2018). Digital Marketing: A Practical Approach. (3rd ed.). Routledge [in English].

Helsen, K. (2019). Digital marketing in the global market place: Latest developments. Retrieved from http://repository.ust.hk/ir/bitstream/1783.1-98195/1/22-MKHEL-2903.pdf [in English].

Kaur, P., Pathak, A., \& Kaur, K.(2015). E-Marketing - A Global Perspective. Journal of Engineering Research and Applications, 5(2), 116-124 [in English].

Maness, J.M. (2019). Library 2.0 Theory: Web 2.0 and Its Implications for Libraries. Retrieved from http://www.webology.org/2006/v3n2/a25.html [in English].

Stokes, R. (2014). eMarketing: The essential guide to marketing in a digital world. (5th ed.). Quirk eMarketing (Pty) Ltd. Red \& Yellow [in English].

Zaveri, B.N., \& Amin, P.D. (2019). Global Marketing Strategy in Digital Era: Global Online Presence. In Breaking Down Language and Cultural Barriers Through Contemporary Global Marketing Strategies (pp. 103-112). IGI Global [in English]. 


$$
\text { УДК 024:[004.77:339.138](477) }
$$

\author{
Tetiana Hranchak, \\ the Head of the Department \\ for the Intellectual Property Protection \\ at the National Library of Ukraine \\ named after V. I. Vernadsky, \\ Dr. Hab. in Social Communications, \\ Senior Research Fellow \\ (Kyiv, Ukraine) \\ e-mail: granchakt@ukr.net \\ ORCID: https://orcid.org/0000-0001-7854-580X
}

\author{
Taisiia Skiter, \\ Master of Information Technology Department at Kyiv \\ National University of Culture and Arts \\ (Kyiv, Ukraine) \\ e-mail: tayaskyter@gmail.com
}

\title{
INTERNET MARKETING IN ACTIVITIES OF LIBRARIES OF UKRAINE
}

Nowadays, library institutions in Ukraine are experiencing a crisis due to a complex of technical, technological, service, methodical, financial, organizational and managerial reasons. One of the ways to overcome the negative tendencies in the development of national libraries and to increase their competitiveness is to introduce Internet marketing as a systematic approach to promoting library products and services into library activities.

The article is devoted to defining the specific features of libraries' of Ukraine Internet marketing. Internet marketing is considered as a set of institution' tools and activities, ranging from the study of the environment (market and market actors in the Internet) and ending with the promotion of Internet brands and the establishment of their service.

Based on the application of the system method, which led to the consideration of certain types of library activities, products and services from the point of view of Internet marketing as a system, methods of content analysis, included monitoring, the experiment, the approaches to the implementation of Internet marketing in the activities of libraries of Ukraine have been characterized.

There has been revealed the use of only some of the tools of Internet marketing within the framework of realization of certain directions of marketing activity by libraries of Ukraine. The main online marketing communications used by Ukrainian libraries today are library sites, libraries' representations on social networks, to a lesser extent, online and traditional media. Libraries conduct campaigns for re-branding, updating the image of institutions, informing users about the modernization of the library information service - providing along with traditional for the libraries products and services the access to online service and innovative interactive events, using the media.

The need to strengthen the analytical and managerial directions of Internet marketing in the library activity is emphasized, namely, to increase the attention to competitor and market research, the effectiveness of functioning of different tools of Internet marketing and implementation of its different directions, as well as the need to develop a well-balanced marketing strategy in the Internet environment and organization its internal marketing processes.

Key words: Internet marketing, library, library activity, library marketing, image, PR, communication. 